\title{
Alcohol and Other Drug Abuse among Cases of Road Traffic Crashes In Port-Said General Hospitals, Egypt 2014
}

\author{
Heba Youssef Mohamed ${ }^{1}$, Mohamed Seif El-din² and Ayat Mahmoud Tawfik ${ }^{3}$ \\ ${ }^{1}$ Forensic Medicine and Clinical Toxicology Department, Faculty of Medicine, Port Said University, Port said, Egypt . \\ ${ }^{2}$ Ministry of health \& population, Egypt \\ ${ }^{3}$ Public Health department, Faculty of Medicine, Port Said University, Port said, Egypt .
}

\begin{abstract}
Background: Road traffic crashes RTC are the leading injury-related cause of death among people aged 15-44 years. A clear dose-effect relationship has been demonstrated for drugs and/or alcohol use and (RTC).

Aim: The objective of this study was to estimate the prevalence of drug and/or alcohol use in cases admitted for RTC to emergency departments in Port-said general hospitals.

Methods: In this study, conducted between January to December 2014, where 1200 cases of road traffic crashes of both sexes and their age were form 18 to 65 years were examined. Toxicological screening urine test was used to detect drugs by the emergency department staff using enzyme linked Immunosorbent assay ELISA. Alcohol and drug of abuse concentration was confirmed from blood samples at the central laboratory using Gas Chromatography Mass Spectrometry GC-MS .

Results: Most of the cases were males, drivers and under 40 years of age. It was found that $70 \%$ of RTC occurred during winter, $34 \%$ at the weekend; Friday and most crashes $(68 \%)$ were caused by trucks. At the time of crashes alcohol was positive in $18.3 \%$ of cases, cannabis positive in $27.5 \%$, tramadol in $47.5 \%$, amphetamine in $8 \%$, cocaine in $1.25 \%$, while sedative hypnotics drugs were positive in only $1.92 \%$.

Conclusion: The risk of road traffic crashes is greatly increased among drivers who tested positive for alcohol, in particular, those who had also ingested tramadol or more psychoactive drugs .

Recommendations: Planning and implementing a national RTC risk management strategy for prevention of mortalities and morbidities due to driving under the influence of drugs. Toxicological screening should be done by immunoassay method followed by confirmation by GC-MS method .
\end{abstract}

Keywords Alcohol, Psychoactive drugs, Road traffic crashes .

\section{Introduction}

$\mathrm{P}$ ort Said is one of the urban governorates of Egypt. It is located in the north-eastern part of the country with a distinguished location overlooking the Suez Canal and the Mediterranean Sea. Its distinguished location gave it its worldwide economic importance and placed it as a trade link. People's main activities are focused on ports services, transit trade, fishing and, recently, industrial activity. Road traffic crashes pose a significant threat to the Egyptian population. Recent estimates revealed that Egypt experiences 42 road traffic deaths per 100,000 populations, which is the highest death rate as ranked by the World Health Organization (WHO) Eastern Mediterranean Region (EMR). Despite the significance of this public health problem, very little risk factor information currently exists regarding alcohol and drugs and its prevalence among driver's cases in Road traffic crash, as well as, studies surrounding this topic are scarce(WHO, 2010)

Traffic accidents represent a major public health issue and alcohol is a well-recognized risk factor for road traffic crashes (RTC) . Driving under the influence of drugs (DUID) other than alcohol is now considered to be an increasing cause of RTC worldwide(Bogstran, Gjerde , and Ekeberg ,2012).Exposure to illicit drugs impairs driving ability owing to their effects on the central nervous system, psychomotor performance, and risktaking behavior. Studies have shown the association between the use of psychoactive substances other than alcohol and increased crash risk ( Morland,2011) . 
Driving under the influence of drugs happens for several reasons. Recreational drug use may be prevalent among people who drive (Honkanen et al., 2012).Drugged driving happens if the driver is a drug user also happen among professional drivers who drive long distances. Drivers who drive under the influence of drugs pose serious risk to others on the road. Although various drugs have different effects, most substances affect driving tasks, even in low dosages. Drug use also increases the probability of poor outcomes following car accidents. It has been shown that risk of death following traffic accidents increases when it is secondary to substance use( Skolnick,2015). Prevention of drugged driving is an essential strategy for prevention of mortalities and morbidities due to unintentional injuries. Authorities, however, cannot design evidence-based policies and programs such as continued drug use education and screening programs if they do not have access to epidemiological information. Such information is essential for the design and implementation of policies that should be enforced to reduce traffic accidents attributed to drugs( Calaft et al .,2012).

As the epidemiological pattern of substance use varies from one geographic location to another, knowledge of local epidemiological patterns of drugged driving is necessary for the improvement of road safety. Screening tests for substances in suspected cases are designed based on the epidemiological information about the type of drugs that are commonly used by drivers who are at high risk of RTC ( Soderstrom, Dischinger and Scalea 2014) . Almost all published epidemiological knowledge in this field originates from North America, Europe, and Australia Different populations are being enrolled to the epidemiological studies on drugged driving. This includes general populations, drivers, professional drivers, and drivers who become involved in crashes (Mason and McBay ,2014). There is very limited information regarding drugged driving in Egypt. The main purpose of the current descriptive study was to investigate the problem of drugged driving in RTC in one of the important trade link city in Egypt.

\section{Aim Of The Work}

This study aims to estimate the prevalence of drug and/or alcohol use in cases of road traffic crashes admitted to emergency departments of Port Said general hospitals.

\section{Methods}

1. Study setting:

This study was conducted in Port Said governorate catchment area and emergency departments of three of its general hospitals, which is designated first target trauma care facility for road traffic victims.

2. Study design and duration :

It was a descriptive study, started from first of January to $31^{\text {st }}$ of December 2014. All motor vehicle driver casualties who presented to the emergency department for treatment of injuries after a crash were approached for assessment. Fatal cases (certified dead in the emergency room) were excluded from the sample. All other injured drivers were considered eligible for recruitment, whatever their outcome after admission with the total number of 1200 cases. All the studied cases were driving the vehicles during the accidents.
a) Inclusion Criteria

All the cases exposed to road traffic injuries were included in this study. Able and willing to provide informed consent.

b) Exclusion Criteria

An injury on road without involvement of the vehicle. (E.g. person slipping or/and falling on the road and sustaining injury).An injury involving a stationary vehicle (e.g. Person getting injured while washing, cleaning and loading a vehicle) People who are not willing to give consent for participation and died cases.

c) Ethical consideration

The urine tests were performed if written informed consent was obtained from the patient or if deemed strongly indicated by the in-charge doctor; to assist management when consciousness was impaired. All eligible injured drivers who were screened had puff of exhaled breath, urine and blood samples and were compared using equivalent cut off concentrations testing for abusive drug exposure, if there were clinical indications for drug screening or if written consent could be obtained. Consenting drivers were reassured that all information obtained would be kept confidential and used for scientific and not legal purposes.

All cases were subjected to the study of the following parameters:

\section{a. Socio-demographic profile :}

Including age, sex, marital status, education, place of accident and occupation. Also the season at which the road traffic crashes occurred and the day of maximum occurrence .

b. Toxicological Testing for Alcohol and drugs of abuse :

I- Toxicological screening

a) Breath analyzer: relies on an indirect measurement of blood alcohol concentration by estimating the amount of alcohol in a puff of exhaled breath. Breathalyzer test is performed only after no less than 20 minutes of careful observation. This amount of time and observation allows for sufficient reason to doubt sobriety or vomiting that may double the alcohol level in the sample of exhaled breath. Breath analyzer screening test cutoff levels for detection of alcohol is $22-25 \mu \mathrm{g} / 100 \mathrm{ml}$ breath (Moore et al., 2014).

b) Enzyme linked Immunosorbent Assay ELISA The use of enzyme immunoassay for the detection of drugs, e.g. ELISA is a quick and convenient method for the analysis of drugs in urine and blood samples and even tissue homogenates. This has been shown to achieve sensitivities and specificities comparable with those of radioimmunoassay, and has the advantage 
of automation. The advantages of using ELISA are; a) no pretreatment as for enzyme multiplied immunoassay technique EMIT, b) small volume of blood (100 $\mu \mathrm{L})$, and $\mathrm{c}$ ) sensitivity $(10 \mathrm{ng} / \mathrm{mL}$ cut-offs for benzodiazepines, cannabinoids, cocaine, opioids). The prevalence of drugs following ELISA analysis and confirmation, will be presented from motor vehicle drivers suspected of driving under the influence of drugs (DUID cases) and also from persons injured in RTC ( Spiehler et al., 2014)

II- Confirmation Test

Gas Chromatography Mass Spectrometry GCMS

Is an analytical method that combines the features of gas-liquid chromatography and mass spectrometry to identify different substances within a test sample. Applications of GC-MS include drug detection (Amirav,Poliak and Fialkov 2011).

The cut off level for detection of drugs and /or their metabolites in urine measured by GCMS are as follow: Tetra hydro cannabinol (THC) $15 \mathrm{ng} / \mathrm{ml}$, benzoylecgonine as cocaine metabolite is $150 \mathrm{ng} / \mathrm{ml}$, codeine $2000 \mathrm{ng} / \mathrm{ml}$, morphine 2000 ng/ml , 6- acetylmorphine 10 $\mathrm{ng} / \mathrm{ml}$, phencyclidine PCP $25 \mathrm{ng} / \mathrm{ml}$, methadone $300 \mathrm{ng} / \mathrm{ml}$, tramadol $10 \mathrm{ng} / \mathrm{ml}$. Amphetamine cut off level is $200 \mathrm{ng} / \mathrm{ml}$ and its metabolites metamphetamine is $500 \mathrm{ng} / \mathrm{ml}$. Barbiturates metabolites cut off value for amobarbital, secobarbital and others is 200 $\mathrm{ng} / \mathrm{ml}$. Benzodiazepines detection level for oxazepam, clonazepam, zolam and diazepam is $200 \mathrm{ng} / \mathrm{ml}$ (Soderstrom et al., 2014)

III- Clinical outcome of cases

\section{c. Calculation of the APACHE equation to assess} the clinical outcome of the studied cases:

This equation is a computerized equation must be done by computer system. It is the result of interaction of the physiological state of the patient, the age and the chronic health problem of the patient. First introduce the lowest and the highest values for the parameter of physiologic state in the $1^{\text {st }} 24 \mathrm{~h}$ which include (temp in $\mathrm{C}^{\circ}$, arterial pressure in $\mathrm{mm} \mathrm{Hg}$, heart rate in beats/minute, respiratory rate in breaths/min, oxygenation, arterial $\mathrm{PH}$, serum glucose, sodium, creatinine, blood urea nitrogen BUN, albumin, bilirubin, hematocrit in percent, white blood cell WBC count in thousands, urine output UOP and Glasgow Coma Score GCS ). Then the sheet continue to be completed and mention if the patient had chronic health problem, the age of the patient and the detected substance or drug abuse, then press on the calculate icon, and the score will be displayed, the predicted mortality and the predicted length of stay will be displayed on the screen (Mazen Kherallah, 2005).

\section{Statistical Analysis}

was done using SPSS windows-version 19. Chi square test was done to test the relation between two variables .In all tests the probability $(\mathrm{P})$ was used; If $\mathrm{P}>0.05$ the relation is non significant. If $\mathrm{P} \leq 0.05$ the relation is significant. If $\mathrm{P} \leq 0.001$ the relation is highly significant. $\mathrm{P} \leq 0.0001$ the relation is very highly significant. The results of statistical analysis were then presented in tables and charts for interpretation and discussion.

\section{Results}

\section{Socio-demographic profile of the studied victims:}

In the current study it was found that most of cases were between 21-40 years age group, accounting for $67.5 \%$ of the total. The male cases represented $93.25 \%$ of them while females were only $6.75 \%$. Regarding the marital status, $80 \%$ were single. Place of accidents showed that $67.5 \%$ of RTC were occurred in urban high speed roads , while the other $32.5 \%$ were occurred in rural areas. All the studied cases were driving the vehicles during the accidents, however, not all of them work as a driver; $91.67 \%$ of them were drivers but the rest $8.33 \%$ were students. In this study 680 cases $(56.67 \%)$ were from intermediate and higher school education and 420 (35\%) were graduates . Most of the accidents occurred during winter( December-February) accounted for $70.83 \%$ .During this study, it was observed that RTC occurred in different frequencies for the days of the week. Fridays represented the most RTC by $34.2 \%$. as shown in table (1).

As regards to types of motor vehicles involved in RTC it was found that trucks were involved in $68 \%$, next to it comes taxi by $12 \%$, while bus, private car and motorcyclist represented $9 \%, 8 \%$ and $3 \%$ respectively, as shown in figure (1).

\section{Toxicological screening for Alcohol and substance abuse}

Breath analyzer for screening of alcohol as well as enzyme immunoassay were performed to detect drugs and substances abuse for all cases exposed to RTC and the results revealed $220(18.33 \%)$ were positive for alcohol, $210(17.5 \%)$ were positive for marijuana, 570 ( $47.5 \%$ ) were positive for tramadol, 56 of cases were positive for sedative hypnotics in the form of $33(2.75 \%)$ for barbiturates and $23 \quad(1.9 \%)$ for benzodiazepines and 14(1.16\%) for amphetamine as shown in table 2 .

Enzyme Linked Immunosorbent assay (ELISA) screening test was performed to the studied cases to detect the presence of drugs and/or their metabolites. Then, a confirmatory test, Gas chromatography mass spectrometry (GC/MS) was performed later to detect drug metabolites for confirmation. Cutoff levels of the detected drugs and drug metabolites were determined at each test, as shown in table (3).

Alcohol in breath of cases exposed to RTC was detected by breath analyzer screening test followed by 
confirmation by detection of alcohol in total blood by GC-MS as shown in table 4

Chi square correlation test was done between drugs of abuse cut off levels confirmed by GC-MS and number and percentage of cases exposed to RTC among cases admitted to emergency department of general hospitals in Port Said governorate during 2014 showed that there was very highly significant value ( $P$ $\left.{ }^{* *} \leq 0.0001\right)$ of drug of abuse cut off level and number and percentage of cases exposed to RTC as shown in table 5 .

Chi square correlation test was done between alcohol cut off levels confirmed by GC-MS and occurrence of RTC among cases admitted to emergency department of general hospitals in Port Said governorate during 2014 showed that there was very highly significant value $\left(\mathrm{P}^{* *} \leq 0.0001\right)$ of alcohol cut off level and number and percentage of cases exposed to RTC as shown in Table 6 .

Outcome results

Acute Physiology And Chronic Health Evaluation (APACHE) score was measured and was higher for the died cases $(n=130)$ than for the survived cases $(n=1070)$. This difference was highly statistically significant ( $\mathrm{p}$ value

Table (1): Socio-demographic criteria among cases exposed to RTC admitted to emergency department of general hospitals in Port Said governorate during year 2014

\begin{tabular}{|c|c|c|}
\hline Socio-demographic criteria & Frequency & Percent \% \\
\hline \multicolumn{3}{|l|}{ 1. Age } \\
\hline$\leq 20$ & 320 & 26.67 \\
\hline $21-40$ & 810 & 67.5 \\
\hline $41-60$ & 60 & 5 \\
\hline$\geq 60$ & 10 & 0.83 \\
\hline \multicolumn{3}{|l|}{ 2. Gender } \\
\hline Male & 1119 & 93.25 \\
\hline Female & 81 & 6.75 \\
\hline \multicolumn{3}{|l|}{ 3. Marital status } \\
\hline Single & 240 & 20 \\
\hline Married & 960 & 80 \\
\hline \multicolumn{3}{|l|}{ 4. Education } \\
\hline Illiterate & 40 & 3.33 \\
\hline Primary school & 60 & 5 \\
\hline High and Intermediate schools & 680 & 56.67 \\
\hline Graduate & 420 & 35 \\
\hline \multicolumn{3}{|l|}{ 5. Place : } \\
\hline Urban/high ways & 810 & 67.5 \\
\hline Rural & 390 & 32.5 \\
\hline \multicolumn{3}{|l|}{ 6. Occupation: } \\
\hline Drivers & 1100 & 91.67 \\
\hline Students & 100 & 8.33 \\
\hline \multicolumn{3}{|l|}{ 7. Season: } \\
\hline Spring (March -May) & 30 & 2.5 \\
\hline Summer (June-August) & 240 & 20 \\
\hline Autumn (September -November) & 80 & 6.67 \\
\hline Winter (December-February ) & 850 & 70.83 \\
\hline \multicolumn{3}{|l|}{ 8. Days of RTC occurrence: } \\
\hline Saturday & 20 & 1.67 \\
\hline Sunday & 320 & 26.7 \\
\hline Monday & 340 & 28.3 \\
\hline Tuesday & 10 & 0.83 \\
\hline Wednesday & 30 & 2.5 \\
\hline Thursday & 70 & 5.83 \\
\hline Friday & 410 & 34.2 \\
\hline Total & 1200 & 100 \\
\hline
\end{tabular}


Table 2:Toxicological screening tests for detection of alcohol ,drugs and substance abuse for cases exposed to RTC admitted to emergency department of general hospitals in Port Said governorate during year 2014

\begin{tabular}{|l|l|l|}
\hline Substance and drug abuse screening results & Number & Percentage \\
\hline Alcohol & 220 & 18.33 \\
\hline Marijuana & 210 & 17.5 \\
\hline Tramadol & 570 & 47.5 \\
\hline Cocaine & 15 & 1.25 \\
\hline Barbiturates & 33 & 2.75 \\
\hline Benzodiazepines & 23 & 1.9 \\
\hline Amphetamines & 14 & 1.16 \\
\hline Total & 1085 & 90.42 \\
\hline
\end{tabular}

Table (3): Cutoff levels for drugs and drug metabolites among the studied cases by ELISA screening followed by GC/MS confirmatory test.

\begin{tabular}{|c|c|c|c|c|}
\hline $\begin{array}{l}\text { Drug or their } \\
\text { metabolites }\end{array}$ & $\begin{array}{c}\text { Detection } \\
\text { time /hours }\end{array}$ & $\begin{array}{l}\text { Cutoff level detected by } \\
\text { ELISA Immunoassay } \\
\text { screening test (ng/ml) }\end{array}$ & $\begin{array}{c}\text { Analyte Metabolites } \\
\text { detected in } \\
\text { confirmation test }\end{array}$ & $\begin{array}{c}\text { Cutoff level detected by } \\
\text { confirmatory GC/MS } \\
\text { test }(\mathrm{ng} / \mathrm{ml})\end{array}$ \\
\hline Marijuana & $6-18$ & 50 & THCA & 15 \\
\hline Opiate metabolites & 2.5 & 2000 & $\begin{array}{l}\text { Codeine } \\
\text { Morphine } \\
\text { 6-acetylmorphine } \\
\text { Phencyclidine PCP } \\
\text { Methadone } \\
\text { Tramadol }\end{array}$ & $\begin{array}{c}2000 \\
2000 \\
10 \\
25 \\
300 \\
10\end{array}$ \\
\hline $\begin{array}{l}\text { Cocaine } \\
\text { metabolites }\end{array}$ & $1.5-4$ & 300 & Benzoylecgonine & 150 \\
\hline Barbiturates & $2-4$ & 200 & $\begin{array}{l}\text { Amobarbital } \\
\text { Secobarbital } \\
\text { Others }\end{array}$ & 200 \\
\hline Benzodiazepines & $2-4$ & 200 & $\begin{array}{l}\text { Oxazepam } \\
\text { Clonazepam } \\
\text { Zolam } \\
\text { Diazepam }\end{array}$ & 200 \\
\hline Amphetamine & $2-4$ & 1000 & $\begin{array}{l}\text { Metamphetamine } \\
\text { Amphetamine }\end{array}$ & $\begin{array}{l}500 \\
200\end{array}$ \\
\hline
\end{tabular}

Table 4: Breath analyzer screening test and GC-MS confirmatory cutoff levels for detection of alcohol

\begin{tabular}{|l|l|l|}
\hline \multirow{2}{*}{$\begin{array}{l}\text { Alcohol } \\
\text { measurement }\end{array}$} & Breath analyzer & Total blood alcohol level GC/MS \\
\cline { 2 - 3 } & $\begin{array}{l}22-55 \text { microgram of alcohol in } 100 \text { milliliters } \\
\text { of breath }\end{array}$ & $\begin{array}{l}70-110 \text { milligrams of alcohol per } 100 \text { milliliters } \\
\text { of blood }\end{array}$ \\
\hline Total & \multicolumn{2}{|c|}{220} \\
\hline Percentage & \multicolumn{2}{|c|}{18.33} \\
\hline
\end{tabular}

Table (5): Chi square correlation between drugs of abuse cut off levels confirmed by GC-Ms and occurrence of RTC among cases admitted to emergency department of general hospitals in Port Said governorate during year 2014

\begin{tabular}{|l|c|c|c|c|c|}
\hline \multicolumn{1}{|c|}{ Drugs or their metabolites } & Cut off level (ng/dl) & Number & \% & X2 & P \\
\hline Marijuana & 15 & 210 & 17.5 & 26.4 & $0.000^{* *}$ \\
\hline Tramadol & 10 & 570 & 47.5 & 69.3 & $0.000^{* *}$ \\
\hline Cocaine & 150 & 15 & 1.25 & 22.7 & $0.000^{* *}$ \\
\hline Barbiturates & 200 & 33 & 2.75 & 17.7 & $0.000^{* *}$ \\
\hline Benzodiazepines & 200 & 23 & 1.9 & 20.4 & $0.000^{* *}$ \\
\hline Amphetamines & 200 & 14 & 1.16 & 15.9 & $0.000^{* *}$ \\
\hline
\end{tabular}

$X 2=$ chi square value $P=$ Level of significance. $\quad P>0.05=$ non significant. $P \leq 0.05=$ significant. $\quad P^{*} \leq 0.001=$ highly significant. $P^{* *} \leq 0.0001$ very highly significant. 
Table (6): Chi square correlation between alcohol cut off level confirmed by GC-MS and occurrence of RTC among cases admitted to emergency department of general hospitals in Port Said governorate during year 2014

\begin{tabular}{|l|l|c|c|c|c|}
\hline Alcohol & $\begin{array}{l}\text { Cut off level } \\
\text { milligrams of alcohol } \\
\text { per 100 milliliters of } \\
\text { blood }\end{array}$ & & Number & X2 & P \\
\cline { 2 - 5 } & $70-110$ & 220 & 18.33 & 27.6 & $0.000^{* *}$ \\
\hline
\end{tabular}

$X 2=$ chi square value $\quad P=$ Level of significance. $\quad P>0.05=$ non significant. $P \leq 0.05=$ significant. $\quad P^{*} \leq 0.001=$ highly significant. $P^{* *} \leq 0.0001$ very highly significant.

Table (7): Comparison of the APACHE score result for the survived and died cases.

\begin{tabular}{|c|c|c|c|}
\hline \multicolumn{2}{|c|}{$\begin{array}{c}\text { APACHE score } \\
\text { Mean } \pm \text { SD }\end{array}$} & t & P-value \\
\cline { 1 - 2 } Survived cases & $\begin{array}{c}\text { Died } \\
\text { cases }\end{array}$ & 4.24 & $0.001^{*}$ \\
\hline $52.5 \pm 6.27$ & $71.6 \pm 10.93$ & & \\
\hline
\end{tabular}

$*$ t-test is statistically significant at level of confidence of $95 \%$.

Figure (1): Types of motor vehicles involved in RTCs among cases admitted to emergency department of general hospitals in Port Said governorate during year 2014 .

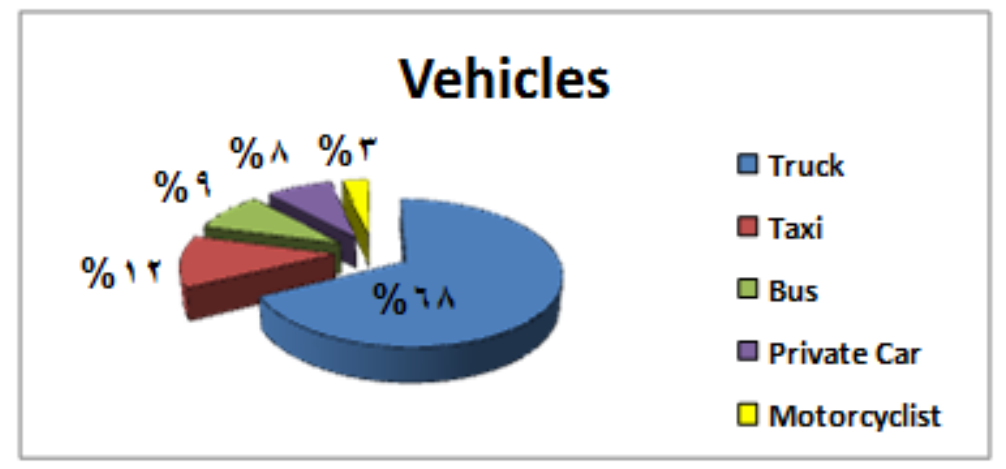

\section{Discussion}

This study revealed that alcohol and other psychoactive drugs misuse was of high prevalence among the cases involved in RTC. The socio demographic profile of the studied cases showed that most of them were in 21-40 years age group, accounting for $67.5 \%$ of the total. Males were much more exposed to RTCs than females. Maximum sex differentiation was observed in age group of 21-40 years with male and female ratio of 19.5:1. Most cases were married and coming from urban residence $(67.5 \%)$. Almost $91.67 \%$ of cases were drivers .High and intermediate school education account for $56.67 \%$. Crashes occurred more in winter season being maximum on Fridays .

Similar results were also observed by Ganveer and Tiwari (2010) in their cross sectional study in central China, where the highest age group of accidents was between 18 to 37 years. Fitzgerald et al ., (2014) had observed the age groups from 15 to 49 years and 31.3 years were the most vulnerable group for the road traffic injuries . Youth, burden of responsibilities, stress, type A' behavioral personality, abuse of alcohol and drugs contribute to the age specificity

Young adults less than 21 years were prone to RTC due to more free time and inefficient driving experience. In addition, they are more likely to engage in "distracted driving" behavior, which describes activities that can endanger the safety of drivers, passengers, and pedestrians as using a cell phone while driving a motor vehicle.

Sex or gender in the road traffic crashes cases was dominated by males. This was due to the obvious reasons like male dominance in driver job performance, lower literacy, family norms, and cultural aspects forcing females to stay at home. This observation was supported by the previous studies by Ngo Anh et al., (2012) who observed the remarkable difference in the gender variation in the cases of road traffic accidents.

In developing countries like Egypt with large clusters of rural populations, RTC might be occur with low or nil education and in urban sectors RTC may be 
high due to density of population, narrow or single roads, intoxicating personal habits etc, though the education was present.

In the current study the higher frequency of road traffic crashes in winter season might be explained by the visibility impairments by early fog and mist, high winds, and rain falls. The study revealed that road traffic crashes were maximum on Fridays this could be explained by the fact that Friday is the week end and a holiday that allow many drivers to drive fast as the roads were less busy with vehicles .

On the other hand the NHTSA (2012) reported that the weekend is the most dangerous day of the week to drive, primarily because there are more cars - and more drunk drivers - on the road than any other day. According to the American Foundation for Traffic Safety, $31 \%$ of fatal drunk-driving accidents occur on the weekend, and the highest number of drunk drivers is on the road between midnight and 3 a.m. Fatal crashes are also four times higher at night than during the day.

In the current study, it was found that trucks were involved in most (68\%)of RTC. This result goes with result identical to that of the American National Highway Traffic and Safety Administration done by RamchandR, et al. (2014) attributing truck accidents to result from driving under influence of alcohol . Moreover, truck accidents are five times more likely to cause serious injuries and death than accidents involving two or more passenger vehicles Movig et al ., (2014).

Alcohol and illicit drugs could affect the driving skills of drivers .Drugs can affect a number of brain functions that adversely influence the ability to drive safely. These can be best categorized as psychomotor and cognitive functions. Psychomotor skills include reaction times and hand-eye coordination while the ability to make appropriate decisions relates to cognitive skills. Foremost among the skills required for safe driving are vigilance, and the ability to interpret traffic situations and to divide attention between tasks. The driver's behavior and attitude also contribute to the risk of having an accident (Blomberg, Peck and Fiorentino ,2013).

The results of present study revealed that there was a highly significant correlation between alcohol and drug abuse cut off level and number and percentage of RTC .

This could be explained by the fact that alcohol and drugs acting on the central nervous system have potential adversely effects on the driving skills. Central nervous system depressants reduce vigilance, increase reaction times and increase errors associated with decision making and speed control in a very similar manner to tramadol, alcohol, benzodiazepines and barbiturates. Drugs that affect behavior may exaggerate adverse behavioral traits and risk-taking behavior. On the other hand during the acute phase of activity, central nervous system stimulants such as amphetamines , cocaine and cannabis tend to reduce performance on divided attention tasks, cause tunnel vision and increase risk taking (Ramaekers, Berghaus and Drummer
2012).They can also cause rebound fatigue, inattention and hyper somnolence when the stimulatory effects wear off (Gjerde et al., 2014) .

Opioid analgesics such as hydromorphone, morphine ,oxycodone and tramadol have direct effects on driving behavior. Cognitive performance is reduced, largely due to their sedative effects, but neuro adaptation rapidly sets in. Driving at night may be a problem due to the persistent miotic effects of these drugs reducing peripheral vision( Karjalainen, Blencowe and Lillsunde,2014 ).Other studies have also found significantly increased risk for crashes associated with the use of alcohol. For instance Soderstrom et al ., (2014) Study found Blood Alcohol concentration (BAC) levels above $0.04 \%$ to be associated with increased accident rates, and higher $\mathrm{BAC}$ levels gave higher accident rates.

In the Netherlands, Movig and his colleagues (2014) found that drivers who tested positive for alcohol (BAC above $0.8 \mathrm{~g} / \mathrm{l}$ ) had an increased likelihood of being injured in RTC.A previous study has shown that the prevalence of alcohol above the legal BAC limit in normal traffic is relatively low in Norway compared to other European countries, which is probably due to the restrictive BAC limits $(0.2 \mathrm{~g} / \mathrm{kg})$ and related sanctions in Norway (Gjerde et al , 2014).

Reviewing the literature on the effect of cannabis compared with alcohol on driving, Sewell and his colleagues (2013) concluded that combining alcohol with marijuana results in impairment even at doses which would be insignificant were they of either drug alone. Moreover, any combination of multiple psychoactive substances was associated with an increased risk of road traffic crashes.

The current work presents good evidence that drivers exposed to road traffic crashes and taking psychoactive drugs, particularly tramadol, cannabis and strong stimulants, or two or more drugs in combination were more likely to be responsible for the crash than those taking neither drugs nor alcohol. Moreover, the combination of psychoactive drugs with alcohol further increased the likelihood that drivers caused the crash in which they died. (Ogden and Moskowitz, 2014) . It is concluded that tramadol, THC ,amphetamines and combinations of psychoactive drugs significantly increase drivers' risk of a serious road crashes.

The current study revealed that higher APACHE score was associated with greater mortality where there is highly significant increase in the APACHE score of died cases when compared to the survived cases.

These results are in agreement with Zimmerman et al. (2013) who assessed the accuracy of APACHE IV score Among 116 ICU admissions and they found that the ratio of observed to predicted mortality was not significantly different and concluded that APACHE IV predictions of ICU mortality are well calibrated and can provide useful marks for evaluating clinical outcome of severe cases.

\section{Conclusion}


- The risk of accident is greatly increased among drivers who tested positive for alcohol, in particular, those who had also ingested one or more psychoactive substances.

- Tramadol was the most abundant drug screened and confirmed in urine of examined cases.

- $\quad$ APACHE IV score is useful tool in predicting of mortality and hospital length of stays in acute intoxicated patients. It can be used as an index of severity in cases exposed to RTC and driving under influence of alcohol and drug abuse .

\section{Recommendation}

Planning and implementing a national RTC risk management strategy for prevention of mortalities and morbidities due to driving under the influence of drugs. Toxicological screening should be done by immunoassay method followed by confirmation by GCMS method .

\section{References}

Amirav, A. Poliak, M. and Fialkov, A. B.(2008):"Gas Chromatography Mass Spectrometry with Supersonic Molecular Beams".Journal of Mass Spectrometry43 (2): 141-163.

Blomberg R., Peck R., and Fiorentino D. (2013):The Long Beach/Fort Lauderdale relative risk study. J Safety Res.; 40:285-292.

Bogstrand S., Gjerde H., and Ekeberg O. (2012):Alcohol, psychoactive substances and non-fatal road traffic accidents - a case-control study.BMC Public Health. ; 12:734.

Calafat .A, et al.( 2012): Traffic risk: drinking, taking drugs, driving, and use of public transport by young people. Traffic InjPrev 10(2):162-9.

Fitzgerald M, et al. (2014) :Drug use in motor vehicle drivers presenting to an Australian, adult major trauma centre .Emerg Med Australas;19:359-65.

Ganveer GB, Tiwari RR.(2010):Injury pattern among non-fatal road traffic accident cases: a crosssectional study in Central India .Indian J Med Sci. 2005 Jan;59(1):9-12.

Gjerde H, et al .,(2014):Alcohol, psychoactive drugs and fatal road traffic accidents in Norway: a casecontrol study. Accid Anal Prev, 43:1197-1203.

Honkanen R., Ertama L., Linnoila M., et al. (2012):Role of drugs in traffic accidents. $\mathrm{Br}$ Med J.; 281:1309-12.

Karjalainen $\mathrm{K}$, Blencowe $\mathrm{T}$ and Lillsunde P(2014):Substance use and social, health and safety-related factors among fatally injured drivers. Accid Anal Prev.;45:731-6.

Mason A. and McBay A. (2013) : Ethanol, marijuana, and other drug use in 600 drivers killed in single-vehicle crashes in North Carolina. J Forensic Sci.; 29:987-1026.

MazenKherallah (2005):The APACHE® IV Equations: Benchmarks for Mortality and Resource Use Description of the revalidation and remodeling of the APACHE equations. Incorporated into
Cerner® Corporation Critical Outcomes (web site) Programmed by MazenKherallah, MD, FCCP.

Moore KA, et al.,( 2014) : Screening urine, blood and tissues for cases of drugs of abuse using automated microplate immunoassay. Forensic Sci Int;106(2):93-102.

Morland J. (2011) :Driving under the influence of nonalcohol drugs. Forensic Sci Rev;12:80-105.

Movig K., et al. (2014):Psychoactive substance use and the risk of motor vehicle accidents.Accid Anal Prev.; 36:631-636.

National Highway Traffic Safety Administration (2007):Results of the 2007 National Roadside Survey of Alcohol and Drug Use by Drivers. U.S. Department of Transportation Report No. DOTHS811175. Washington, DC: National Highway Traffic Safety Administration.

Ngo AD et al ., 2012:PS.Road traffic related mortality in Vietnam: evidence for policy from a national sample mortality surveillance system.BMC Public Health. 2012 Jul 27;12:561. doi:

Ogden E. and Moskowitz H.(2014):Effects of alcohol and other drugs on driver performance. Traffic Inj Prev.; 5(3):185-98.

Ramaekers JG, Berghaus $\mathrm{G}$ and Drummer $\mathrm{OH}$. (2012)Dose related risk of motor vehicle crashes after cannabis use.

Drug Alcohol Depend;73:109-19.Forensic Sci Rev;14:114.

RamchandR , et al. (2014):Alcohol abuse and illegal drug use among Los Angeles County trauma patients: prevalence and evaluation of single item screener. J Trauma.;66(5):1461-7

Sewell RA, Poling J and Sofuoglu M.(2013):The effect of cannabis compared with alcohol on driving. Am J Addict, 18:185-193.

Skolnick A. (2015):Illicit drugs take still another tolldeath or injury from vehicle-associated trauma. JAMA.; 263:3122-3125.

Soderstrom CA, et al. (2014):The accuracy of the CAGE, the Brief Michigan Alcoholism Screening Test, and the Alcohol Use Disorders Identification Test in screening trauma center patients for alcoholism.J Trauma.;43(6):962-9.

Soderstrom C., Dischinger P., and Scalea T.( 2014):Epidemic increases in cocaine and opiate use by trauma center patients: documentation with a large clinical toxicology database. J Trauma.; 51: 57-64.

Spiehler VR et al .,( 2014): Validation of an automated enzyme immunoassay for screening of urine and blood for drugs of abuse. $\mathbf{J}$ Anal Toxicol;22(7):573-9.

Sloan, K. M.; Mustacich, R. V. ;and Eckenrode, B. A. (2011):"Development and evaluation of a low thermal mass gas chromatograph for rapid forensic GC-MS analyses". Field Analytical Chemistry \& Technology5 (6): 288. 
World Health Organization(2010):Summary of the report from the WHO collaborative study on alcohol and

injuries.website:http://www.who.int/substance_a buse/publications/alcohol_injury_summary.pdf Accessed 25 Feb 2010.
Zimmerman M, Andrew K, Douglas S, et al.(2013). Acute physiology and chronic health evaluation (APACHE) IV ICU length of stay benchmarks for today's critically ill patients. Crit Care Med. May; 34(5):1297.

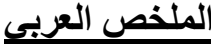

الكحول وتعاطي المخدرات الأخرى بين ضحايا حوادث المرور التصادمية مستشفيات بورسعيد العامة ، مصر r. I $1 \varepsilon$

هبة يوسف محمد او محمد سيف الدين r و آيات محمود توفيقr

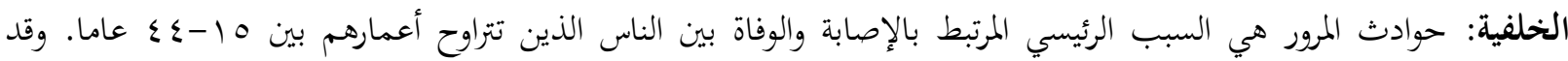

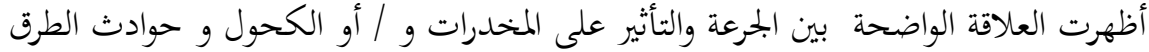

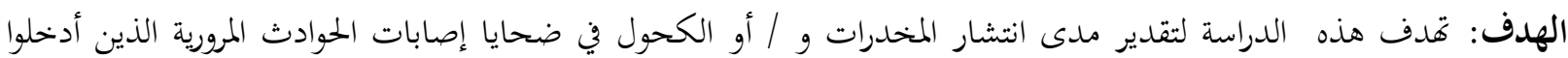
لاقسام الطواريء بمستشفيات بورسعيد العامة

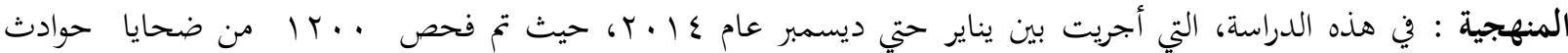

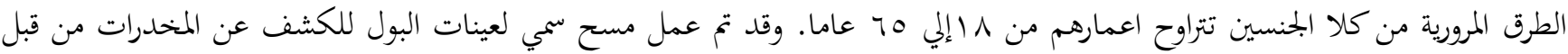

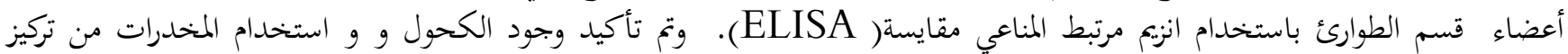

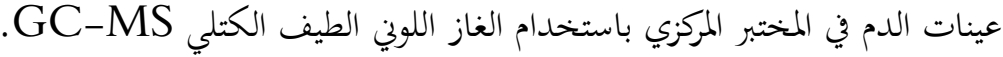

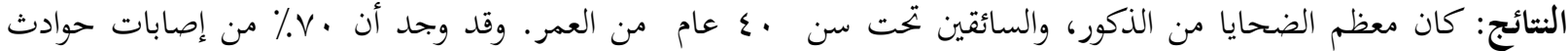

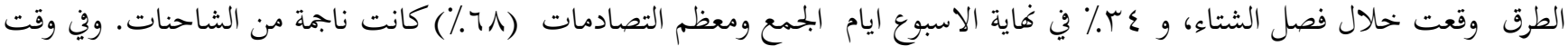

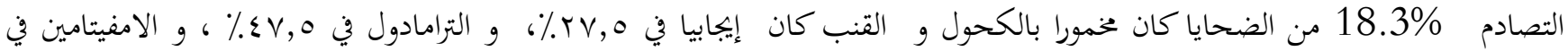

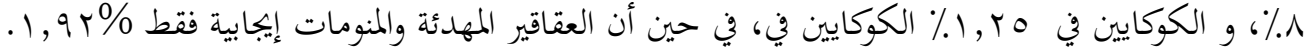

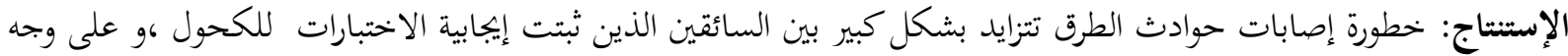

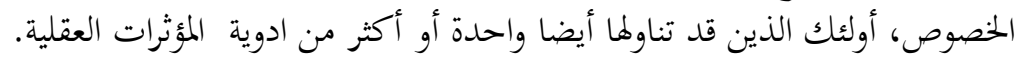

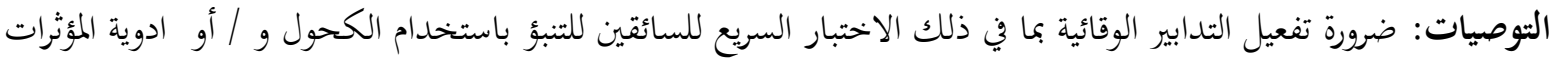

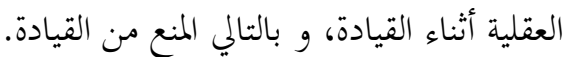

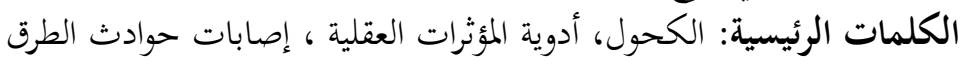

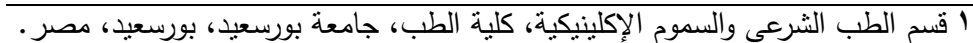

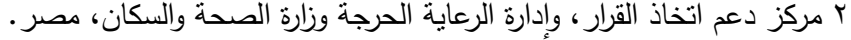

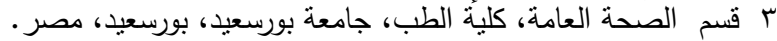

